\title{
MENINGKATKAN HASIL BELAJAR SISWA MATERI MASALAH SOSIAL DENGAN MENERAPKAN MODEL PEMBELAJARAN GROUP INVESTIGATION
}

\author{
Hariatun Insiah \\ SDN 18 Lubklinggau \\ hariatun2018@gmail.com
}

\begin{abstract}
ABSTRAK
Tujuan penelitian, untuk meningkatkan hasil belajar materi masalah sosial siswa Kelas IV SD Negeri 18 Lubuklinggau dengan menerapkan model pembelajaran group investigation. Penelitian ini menggunakan pendekatan penelitian tidakan kelas (action research). Pelaksanaan penelitian dilakukan pra siklus pada hari tanggal 15 April 2018, siklus 1 pada tanggal 21 April 2018 dan siklus II pada 28 April 2018. Hasil penelitian, pada pratindakan didapat nilai 10 siswa $(43,47 \%)$ yang mengalami ketuntasan sedangkan 13 siswa $(56,53 \%)$ yang belum tuntas. Sedangkan pada siklus I di dapat 13 siswa yang tuntas (56,52\%) dan 10 siswa yang belum tuntas $(43,48)$. Pada siklus II didapat 20 siswa $(86,95 \%)$ yang tuntas dan 3 siswa $(13,05)$ yang belum tuntas. Simpulan, penerapan model pembelajaran group investigation dapat meningkatkan hasil belajar siswa
\end{abstract}

Kata Kunci: Hasil Belajar, Model Pembelajaran, Group Investigation,

\begin{abstract}
The aim of the study was to improve students achievement in learning social problems at the forth grade students of SD Negeri 18 Lubuklinggau by using group investigation model. The study was a classroom action research (CAR). The study was conducted such as pre cycle was on April 15th 2018, cycle I was on April 21st 2018, and cycle II was on April 28th 2018. The result: there were 10 students $(43,47 \%)$ who pass the passing grade and 13 students $(56,53 \%)$ who fail. In cycle I, there were 13 students who pass $(56,52 \%)$ and 10 students who fail $(43,48)$. In cycle, there were 20 students (86,95\%) who pass and 3 students $(13,05)$ who fail. In conclusion, the application of group investigation model improved students learning achievement.
\end{abstract}

Keywords: Learning Achievement, Teaching Method, Group Investigation, 


\section{PENDAHULUAN}

Mata pelajaran PKn merupakan salah satu mata pelajaran yang diujikan di Ujian Sekolah pada setiap akhir tahun pelajaran yang juga ikut menentukan predikat kelulusan setiap siswa SD, karena dari pelajaran PKN tersebut diharapkan siswa mampu meningkatkan kepekaan terhadap masalah-masalah sosial disekitarnya serta mampu menerapkan ilmu yang mereka dapat dalam kehidupan mereka sehari-hari sehingga penguasaan terhadap materi pelajaran PKN perlu mendapat perhatian khusus. Salah satu materi ajar yang perlu mendapat perhatian khusus itu adalah pada bab perang dunia II yang konten materinya begitu banyak jalinan cerita yang bersifat kronologis serta bersifat berurut.

Permasalahannya kondisi siswa di pembelajaran seringkali didominasi oleh kegiatan menulis, mencatat, mendengarkan guru menerangkan, membaca buku. Semua itu adalah aktivitas yang dilakukan oleh otak kiri saja sehingga siswa sering merasa bosan untuk belajar dan kurang memiliki inisiatif untuk aktif secara individu maupun berkelompok.

Problem lainnya juga nampak pada sebuah momen pembelajaran seringkali jika guru memanggil siswa untuk tampil di depan kelas pemandangan yang terjadi nyaris selalu ada dua kondisi yang muncul yaitu ada siswa yang dengan mudah dipanggil maju ke depan kelas, sebaliknya banyak siswa yang selalu sulit untuk memberanikan diri tampil ke depan kelas. Hal lain lagi yang sering terlihat para siswa kurang terkondisi dalam keadaan bahwa tiap individu siswa memiliki peluang yang sama untuk dilibatkan secara aktif, seharusnya tidak melulu para siswa yang pandai saja yang aktif tetapi siswa lainnya pun dapat berperan lebih aktif dari biasanya. Untuk itu perlu dipikirkan model pembelajaran yang memungkinkan semua siswa aktif seperti beberapa model pengelompokkan yang telah banyak kita kenal.

Model pembelajaran yang didominasi oleh guru melalui ceramahceramahnya menyampaikan sejumlah informasi/materi pelajaran yang sudah disusun secara sistematis mengkondisikan siswa dalam tingkat partisipasi yang rendah serta siswa sering berada dalam situasi "tertekan" yang berakibat pada tidak optimalnya pemusatan perhatian pada kemampuan yang harus dikuasainya menjadi rendah termasuk juga aktivitas belajar yang kurang menantang siswa untuk melakukan kerja yang maksimal (Ahmadi, 2007). Dan kalau hal ini terus berlanjut maka tujuan pengajaran PKN yang telah disampaikan di atas tidak dapat tercapai.

Selain itu, hal yang menjadi hambatan selama ini adalah pembelajaran PKN oleh guru seringkali dikemas dengan cara yang konvensional atau tradisional yang selalu melaksanakan rutinitas yang cenderung mengendapkan kreativitas serta seperti menutup mata terhadap perkembangan IPTEK yang namun semua itu seperti terabaikan begitu saja. Dalam hal ini media pembelajaran yang digunakan oleh guru kurang menarik minat para siswa (Daldiyanto, 2009). 
Untuk itulah diperlukan inovasi pembelajaran yang dapat diterapkan untuk mendorong terciptanya pembelajaran PKN dalam hal ini materi masalah sosial yang berkualitas yang berangkat dari pendekatan pembelajaran yang berpusat kepada siswa. Atas dasar semua itu, perlu adanya upaya-upaya agar segala hambatan yang selama ini berlaku dapat segera diatasi. Upaya-upaya yang mampu mengkondisikan seluruh siswa dapat aktif dalam proses pembelajaran. Salah satu cara agar pembelajaran PKN dapat berlangsung dalam suasana aktif, kreatif, efektif, dan menyenangkan (PAKEM) adalah dengan penerapan model pembelajaran investigasi kelompok (Dimyati, 2009).

Pembelajaran group investigation merupakan salah satu bentuk model pembelajaran kooperatif yang menekankan pada partisipasi dan aktivitas siswa untuk mencari sendiri materi (informasi) pelajaran yang akan dipelajari melalui bahan-bahan yang tersedia, misalnya dari buku pelajaran atau siswa dapat mencari melalui internet. Siswa dilibatkan sejak perencanaan, baik dalam menentukan topik maupun cara untuk mempelajarinya melalui investigasi (Suyatno, 2009). Model ini menuntut para siswa untuk memiliki kemampuan yang baik dalam berkomunikasi maupun dalam keterampilan proses kelompok. Model group investigation dapat melatih siswa untuk menumbuhkan kemampuan berfikir mandiri. Keterlibatan siswa secara aktif dapat terlihat mulai dari tahap pertama sampai tahap akhir pembelajaran.

\section{METODE PENELITIAN}

Penelitian ini merupakan penelitian tidakan (action research), karena penelitian dilakukan untuk memecahkan masalah pembelajaran di kelas. Penelitian ini juga termasuk penelitian deskriptif, sebab menggambarkan bagaimana suatu teknik pembelajaran diterapkan dan bagaimana hasil yang diinginkan dapat dicapai. Perbaikan pembelajaran dilakukan melalui Penelitian Tindakan Kelas (PTK) yang terdiri atas dua siklus. Setiap siklus kegiatan yang dilakukan meliputi : 1) Perencanaan; 2) Pelaksanaan; 3) Observasi / pengamatan; dan 4) Refleksi (Barkey, 2005).

\section{HASIL PENELITIAN}

\section{Deskripsi Kondisi Awal}

Subjek penelitian ini adalah kelas IV SD Negeri 18 Lubuklinggau yang berjumlah 23 siswa, dengan jumlah 18 orang siswa perempuan dan 5 orang siswa laki-laki. Sebelum melakukan model pembelajaran Investigasi Kelompok terlebih dahulu diberikan tes awal yang bertujuan untuk mengetahui kemampuan awal siswa dalam memahami masalah sosial. Hal ini dilakukan karena kemampuan awal ini sangat diperlukan untuk mengetahui tingkat kesukaran siswa dalam memahami masalah sosial.

Setelah dianalisis (lampiran) didapat bahwa siswa yang mendapat nilai lebih dari 60 (tuntas) dalam tes awal ini sebanyak 10 siswa $(43,47 \%)$ dan yang nilainya 
kurang dari 60 (belum tuntas) adalah 13 siswa (56,53\%). Nilai yang tertinggi adalah 70 dan yang terendah adalah 30 . Rata-rata $(\bar{x})$ nilai secara keseluruhan sebesar 48,26. Jadi secara deskriptif dapat dikatakan bahwa kemampuan awal siswa belum termasuk kategori tuntas, karena nilai rata-ratanya kurang dari 60 ( $\bar{x}<60$ ). Berikut kami sajikan ketuntasan prasiklus dalam bentuk lingkaran berikut:

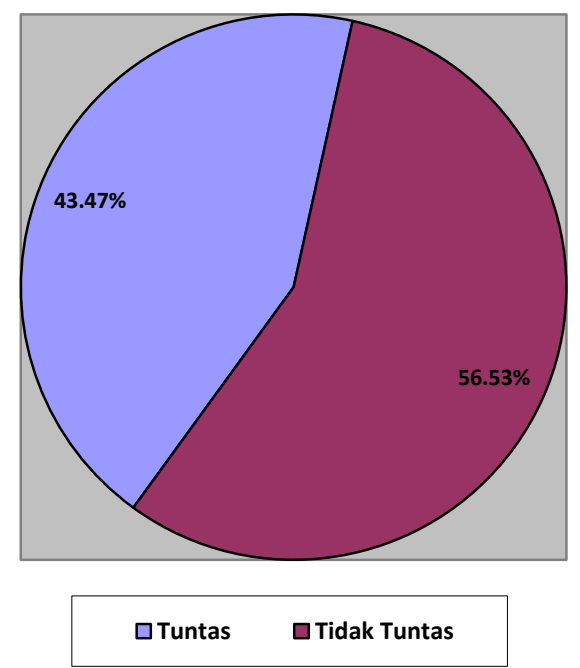

Grafik 1 Persentase Ketuntasan Pra Siklus

Rendahnya nilai tes pada refleksi awal ini disebabkan antara lain, penggunaan metode pada siswa masih menggunakan metode ceramah, jadi siswa merasa bosan, kurang berminat dan tidak aktif dalam proses KBM-nya. Atas dasar temuan ini peneliti menyimpulkan bahwa untuk mencapai hasil belajar yang baik, diperlukan satu metode yang dapat menarik minat siswa untuk aktif dalam proses KBM sehingga belajar akan terlihat efisien.

\section{Deskripsi Siklus I}

Setelah dilakukan tes pada akhir pembelajaran, maka diperoleh hasil tes siswa yang dapat dilihat lampiran. Berdasarkan perhitungan pada hasil siklus I ini dapat dilihat bahwa siswa yang mendapat nilai lebih dari 60 (tuntas) dalam tes sebanyak 13 siswa $(56,52 \%)$ dan yang nilainya kurang dari 60 (belum tuntas) adalah 10 siswa $(43,48 \%)$. Nilai yang tertinggi adalah 80 dan yang terendah adalah 40. Rata-rata $(\bar{x})$ nilai secara keseluruhan sebesar 57,40. Jadi secara deskriptif dapat dikatakan bahwa kemampuan siswa siklus I belum termasuk kategori tuntas, karena nilai rata-ratanya kurang dari $60(\bar{x}<60)$. Berikut kami sajikan ketuntasan siklus I dalam bentuk lingkaran berikut: 


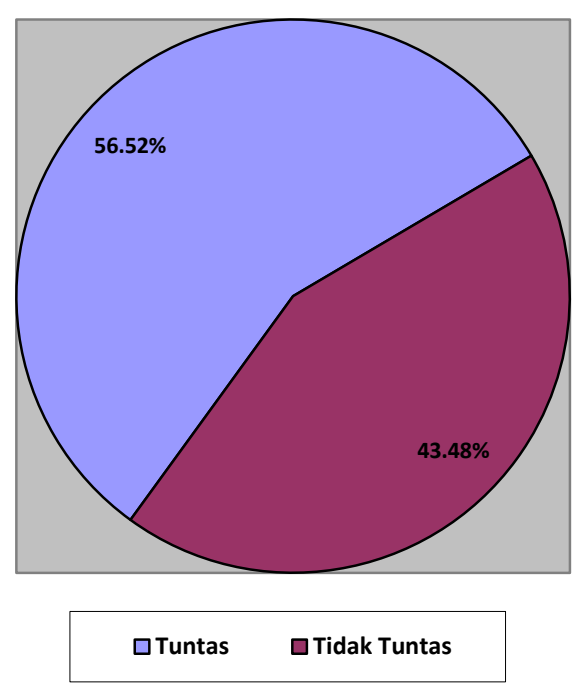

\section{Grafik 2 Persentase Ketuntasan Siklus I}

Namun terjadi peningkatan belajar siswa dari pratindakan ke siklus I, hal ini terlihat pada nilai rata-rata pratindakan sebesar 48,26 sedangkan pada nilai rata-rata siklus I sebesar 57,40 berarti terjadi peningkatan sebesar 9,14 pada pratindakan ketuntasan belajar siswa sebanyak 10 siswa $(43,47 \%)$ dan pada siklus I siswa yang tuntas berjumlah 13 orang (56,52\%). Inipun dapat dilihat terjadi peningkatan yang signifikan sebasar $18,94 \%$.

\section{Deskripsi Siklus II}

Setelah dilakukan tes pada akhir pembelajaran, maka diperoleh hasil tes siswa yang dapat dilihat dilampiran. Berdasarkan hasil analisis data pada siklus II ini dapat dilihat bahwa siswa yang mendapat nilai lebih dari 60 (tuntas) sebanyak 20 siswa (86,95\%) dan yang nilainya kurang dari 60 (belum tuntas) adalah 3 siswa $(13,05 \%)$. Nilai yang tertinggi adalah 100 dan yang terendah adalah 50 . Rata-rata $(\bar{x})$ nilai secara keseluruhan sebesar 73,48. Jadi secara deskriptif dapat dikatakan bahwa kemampuan awal siswa belum termasuk kategori tuntas, karena nilai rataratanya kurang dari $60(\bar{x}<60)$.

Bila diperhatikan terjadi peningkatan belajar siswa dari siklus I ke siklus II, hal ini terlihat pada nilai rata-rata siklus I sebesar 57,40 sedangkan pada nilai rata-rata siklus II sebesar 73,48 berarti terjadi peningkatan sebesar 16,08 pada siklus I ketuntasan belajar siswa sebanyak 13 orang $(56,52 \%)$ dan pada siklus II siswa yang tuntas berjumlah 20 orang (86,92\%). Inipun dapat dilihat terjadi peningkatan yang signifikan sebasar 28,01\%. Berikut kami sajikan ketuntasan siklus II dalam bentuk lingkaran berikut: 


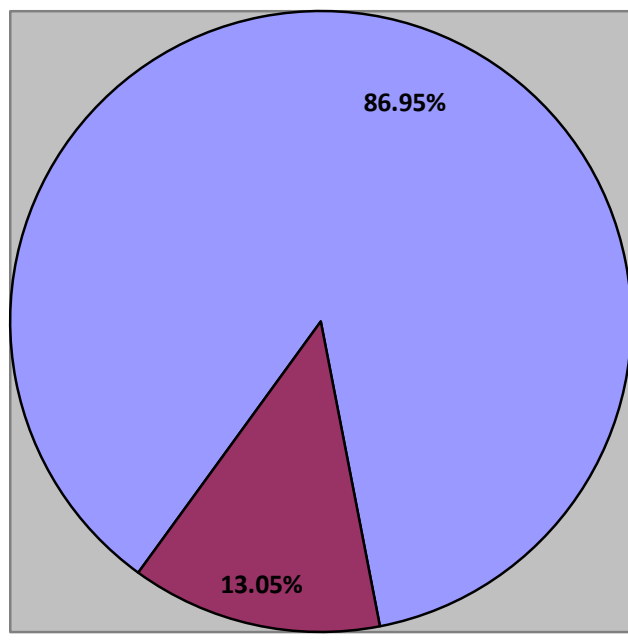

$\square$ Tuntas $\quad \square$ Tidak Tuntas

Grafik 3 Persentase Ketuntasan Siklus II

Kesulitan dalam memahami materi masalah sosial pada siklus I tidak terjadi lagi pada siklus II. Pada siklus II ini siswa mengalami peningkatan dalam materi masalah sosial, walaupun ada sebagian kecil siswa yang masih kesulitan dalam materi masalah sosial.

\section{PEMBAHASAN}

\section{Peningkatan Aktifitas Siswa dengan Model Pembelajaran Investigasi Kelompok}

Sebelum melakukan tindakan pertama, terlebih dahulu peneliti mengadakan refleksi awal (pratindakan) untuk mengetahui permasalahan yang sebenarny.. Untuk memperoleh data, peneliti memberikan tes Pangaren Diponegoro. Selanjutnya data akan diolah untuk melihat persentase belum tuntas dan telah tuntas anak. Setelah diolah didapat masih banyak siswa yang belum tuntas.

Rendahnya hasil pada refeksi awal atau pratindakan dikarenakan penggunaan metode pengajaran yang digunakan selama ini masih kurang efektif dan tepat guna. Metode yang digunakan adalah metode ceramah yang diselingi dengann metode tanya jawab. Metode ini tidak mendukung tercapainya kemampuan siswa dikarenakan metode tersebut kurang dapat membangkitkan motivasi siswa. Oleh karena itu peneliti mencoba model pembelajaran Investigasi Kelompok.

Motivasi belajar siswa dalam upaya meningkatkan hasil relajar setelah dilakukan penerapan model pembelajaran Investigasi Kelompok terlihat. Hal ini dapat tercermin pada aktifnya siswa dalam proses kegiatan belajar, semua siswa 
semangat dalam memperhatikan penjelasan dan pertanyaan dari guru. Walaupun masih ada beberapa siswa yang masih pasif namun hal itu tidak mempengaruhi proses motivasi belajar siswa karena beriringnya pelaksanaan siklus I dan siklus II beberapa siswa yang pasif tadi akhirnya sedikit demi sedikit aktif.

Hasil belajar siswa kelas IV SD Negeri 36 Lubuklinggau pada materi pengenalan tokoh pahlwan setelah dilakukan penerapan model pembelajaran Investigasi Kelompok peneliti paparkan bahwa hasil tes pratindakan, hasil tes tindakan siklus I, hasil tes tindakan siklus II terjadi peningkatan.

\section{Peningkatan Hasil Belajar Siswa dengan Model Pembelajaran Investigasi Kelompok}

Pada pelaksanaan pratindakan diperoleh bahwa dari 23 orang siswa terdapat 10 orang $(43,47 \%)$ siswa yang mencapai ketuntasan belajar, sedangkan 13 orang $(56,53 \%)$ siswa yang belum mencapai ketuntasan belajar. Setelah diterapkan model pembelajaran Investigasi Kelompok, pada siklus I diperoleh bahwa dari 23 orang siswa terdapat 13 orang $(34,15 \%)$ siswa yang belum mencapai ketuntasan. Dalam hal ini ketuntasan belajar PKN siswa secara klasikal belum tercapai, untuk itu diperlu dilanjutkan pada siklus II.

Selama pelaksanaan siklus II banyak hal-hal yang terjadi seperti siswa yang menerima tongkat, ada yang harap-harap cemas jangan dia yang mendapat giliran mendapat tongkat sehingga dia selalu gelisah. Kegelisahan ini mungkin mereka kurang mengerti tentang materi yang diajarkan atau mungkin juga dia merasa takut akan jawabannya salah. Ada juga yang selalu siap menunggu datangnya tongkat karena ia sudah mengerti akan jawaban soal yang akan diberikan. Selain itu juga dia telah mengerti akan metode yang diterapkan sehingga mereka anggap itu hal yang baik. Keaktifan siswapun sangat beragam, ada yang sangat aktif, ada yang biasa saja namun tidak ada yang pasif. Semunya ikut membaur akan metode yang diterapkan.

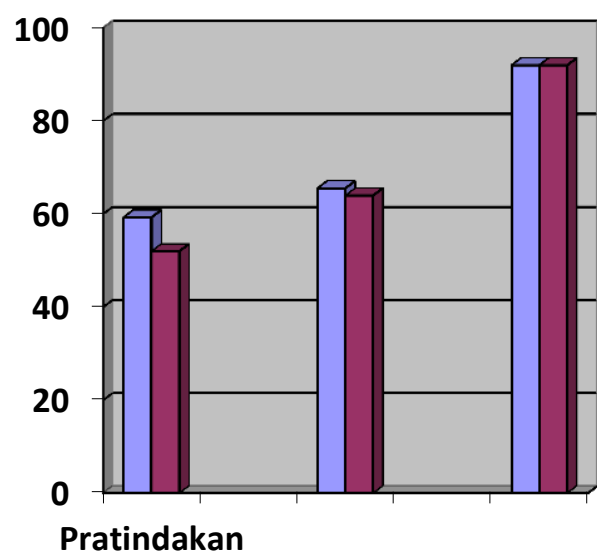

$\square$ Nilai Rata-Rata

$\square$ Persentase Tuntas

Gambar 4 NIlai Rata-Rata dan Ketuntasan Prasiklus, Siklus I dan Siklus II 
Setelah tindakan pada siklus II dari tes soal yang diberikan, diperoleh 23 orang siswa terdapat 20 orang $(86,95 \%)$ siswa mencapai ketuntasan belajar dan hanya 3 orang $(13,05 \%)$ siswa yang belum mencapai ketuntasan belajar. Sampainya ketuntasan belajar siswa yang diharapkan merupakan hasil refleksi dari kesalahan pada siklus I sehingga peneliti bisa memperbaiki segala sesuatu yang kurang. Walaupun semua kesalahan telah diperbaiki namun semuanya belum sempurna karena masih ada yang belum sesuai dengan yang diharapkan. Akan tetapi persentase ketidak sempurnaan itu kecil karena bisa ditutupi dengan keberhasilan siswa dalam ketuntasan belajar yang ditetapkan.

Penelitian ini menyimpulkan bahwa model pembelajaran Investigasi Kelompok dapat meningkatkan hasil belajar siswa di kelas IV SD Negeri 18 Lubuklinggau. Dengan demikian berarti nilai siswa setiap diadakan tindakan mengalami kenaikan atau peningkatan. Hal ini membuktikan bahwa hipotesis peneliti dapat dibuktikan kebenarannya. Bahwa dengan penerapan model pembelajaran Investigasi Kelompok kepada siswa, maka akan dapat meningkatkan hasil belajar sejarah siswa kelas IV SD Negeri 18 Lubuklinggau. Dalam hal ini prestasi belajar siswa meningkat dan tercapainya ketuntasan belajar, berarti penggunaan model pembelajaran Investigasi Kelompok pada waktu pelajaran sejarah di kelas dapat meningkatkan hasil belajar siswa.

\section{SIMPULAN}

Motivasi belajar siswa dalam upaya meningkatkan hasil relajar setelah dilakukan penerapan model pembelajaran Investigasi Kelompok terlihat. Hal ini dapat tercermin pada aktifnya siswa dalam proses kegiatan belajar, semua siswa semangat dalam memperhatikan penjelasan dan pertanyaan dari guru. Walaupun masih ada beberapa siswa yang masih pasif namun hal itu tidak mempengaruhi proses motivasi belajar siswa karena beriringnya pelaksanaan siklus I dan siklus II beberapa siswa yang pasif tadi akhirnya sedikit demi sedikit aktif. Pada pratindakan didapat nilai 10 siswa $(43,47 \%)$ yang mengalami ketuntasan sedangkan 13 siswa $(56,53 \%)$ yang belum tuntas. Banyaknya siswa yang belum tuntas ini karena siswa belum diterapkan metode yang diterapkan. Sedangkan pada siklus II di dapat 13 siswa yang tuntas $(56,52 \%)$ dan 10 siswa yang belum tuntas (43,48). Pada siklus II didapat 20 siswa $(86,95 \%)$ yang tuntas dan 3 siswa $(13,05)$ yang belum tuntas. Hal ini membuktikan bahwa penerapan model pembelajaran Investigasi Kelompok dapat meningkatkan hasil belajar siswa. 


\section{DAFTAR PUSTAKA}

Ahmadi. (2007). Model-model Pembelajaran. Jakarta : Penerbit Rineka Cipta

Barkey. (2005). Pembelajaran Kolaboratif dalam Pratek Kelas. [Online] http://makalahkumakalamu.blogspot.com/2011/21/\&*7 . [8 Juli 2012]

Daldiyono. (2009). Psikologi dalam Meningkatkan Kemampuan Anak. Jakarta: Rineka Cipta.

Dimyati \& Mudjiono. (2009). Belajar dan Pembelajaran. Jakarta : Penerbit Rineka Cipta.

Suyatno. (2009). Menjelajah Pembelajaran Inovatif. Sidoarjo: Masmedia Buana Pustaka. 